\title{
ANALIZA SKUTKÓW WDROŻENIA SPECUSTAWY JAKO PROCEDURY PRZYGOTOWANIA INWESTYCJI DROGOWYCH W POLSCE
}

\author{
Mieczysław Połoński®1, Katarzyna Zawadewicz² \\ ${ }^{1}$ Wydział Budownictwa i Inżynierii Środowiska, Szkoła Główna Gospodarstwa Wiejskiego w Warszawie, Warszawa \\ ${ }^{2}$ Mazowiecki Urząd Wojewódzki, Warszawa
}

\begin{abstract}
STRESZCZENIE
Z chwilą przystąpienia Polski do Unii Europejskiej uzyskano dostęp do znacznych środków finansowych, m.in. na rozbudowę infrastruktury drogowej. Jedną z barier ograniczających wykorzystanie tych środków są procedury prawne związane z przygotowaniem i realizacją tych inwestycji. W celu usprawnienia procesu inwestycyjnego w tym zakresie Sejm uchwalił specjalny akt prawny nazywany popularnie specustawą drogową. Wszedł on w życie w 2003 roku i będzie obowiązywał do 2023 roku. Ponieważ akt ten obowiązuje już ponad 10 lat, w artykule przeanalizowano skutki jego działania, zarówno pozytywne, jak i negatywne. Stwierdzono, że ustawa jest niezbędnym narzędziem prawnym do szybkiej realizacji sieci dróg w Polsce. Jest ona chętnie, skutecznie oraz maksymalnie wykorzystywana w procesie przygotowania i realizacji tych inwestycji. Kumulacja kilku postępowań administracyjnych w jednym daje inwestorom wiele możliwości prawnych sprawnej i szybkiej realizacji tych obiektów. Jednak zawarte w niej uproszczenia proceduralne podnoszą ryzyko popełnienia błędu, powodującego trudne do odwrócenia skutki zarówno techniczne, jak i prawne. Głównymi problemami przy stosowaniu specustawy jest wysokość wypłacanych odszkodowań za przejęte tereny oraz próby wywłaszczenie ponad zakres niezbędny i konieczny dla realizacji planowanej inwestycji drogowej.
\end{abstract}

Słowa kluczowe: specustawa drogowa, inwestycje drogowe, przygotowanie inwestycji, proces inwestycyjny, prawo budowlane

\section{WSTĘP}

Przygotowanie i realizacja inwestycji budowlanych prawie zawsze jest procesem żmudnym, wymagającym dużego nakładu czasu i środków finansowych (Połoński, red., 2009; Sobotka, Jaśkowski, Czarnigowska, Pawluś i Wałach, 2014). Dotyczy to zwłaszcza inwestycji liniowych, przecinających znaczną liczbę działek, o różnym stanie prawnym, uzbrojeniu technicznym, warunkach środowiskowych itp. $Z$ drugiej strony istnieje olbrzymie oczekiwanie społeczne na szybką i sprawną realizację tych inwestycji, niezbędnych do rozwoju gospodarczego i cywilizacyjnego kraju. Konieczność przyspieszenia tych prac związana jest również z ograniczonym czasowo horyzontem dostępu do dotacji z funduszy europejskich. Analizując przebieg procesu inwestycyjnego w latach ubiegłych, zauważono, że jedną z głównych barier ograniczających tempo realizacji inwestycji drogowych są uregulowania prawne, dotyczące przeprowadzania wymaganych do uzyskania pozwolenia na budowę procedur administracyjnych.

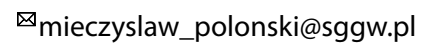


Wszystkie decyzje, pozwolenia i uzgodnienia, jakie powinien uzyskać inwestor, aby zrealizować przedsięwzięcie przed rozpoczęciem budowy obiektu, są wydawane przez organy administracji publicznej. Organy te działają na podstawie przepisów prawa, co normuje Ustawa z dnia 14 czerwca 1960 r. - Kodeks postępowania administracyjnego (Dz.U. 1960 nr 30 poz. 23 z późn. zm). Do 2003 roku, poza Kodeksem postępowania administracyjnego (Kpa), głównymi aktami regulującymi procedurę uzyskania pozwolenia na budowę dróg były: Prawo budowlane i Ustawa z 21.03.1985 roku o drogach publicznych. Jednym z podstawowych problemów, które powodowały znaczne wydłużenie w czasie uzyskania prawomocnego pozwolenia na budowę (pomijając zagadnienia związane z uzyskaniem decyzji środowiskowej), był dostęp do terenu, na którym miała być zlokalizowana planowana inwestycja. Było to szczególnie istotne w przypadku inwestycji liniowych, gdyż obiekty tego typu przecinały najczęściej bardzo dużą liczbę działek, z których przynajmniej część była w rękach prywatnych. Do tego często dochodziły problemy z ustaleniem ich stanu prawnego, gdyż np. właścicielami była grupa osób, toczyło się postępowanie spadkowe czy spór sądowy o prawo własności. Niektóre działki były dzierżawione, inne posiadały obciążoną hipotekę lub ustanowiony zastaw bankowy. W innych przypadkach były nawet kłopoty z ustaleniem właściciela lub brak możliwości nawiązania z nim kontaktu. A przecież jednym z podstawowych warunków wydania pozwolenia na budowę jest prawomocny dostęp do terenu, na którym ma być zlokalizowana inwestycja. Świadomość tych trudności oraz ograniczonego w czasie dostępu do dotacji unijnych skłoniły ustawodawcę do przygotowania odrębnej regulacji prawnej, która pozwoliłaby ten proces zdecydowanie usprawnić. W ten sposób doszło do powstania ustawy, zwanej zazwyczaj specustawą drogową.

Celem artykułu jest przeanalizowanie na podstawie ponad dziesięcioletnich doświadczeń skutków działania tego aktu prawnego, zarówno pozytywnych, jak i negatywnych. Szczególną uwagę skupiono na możliwości usprawnienia procesu ubiegania się o wydanie decyzji ZRID oraz problemie wyceny i wypłat należnych odszkodowań za wywłaszczenia, niezbędne do realizacji inwestycji drogowych. Analizy opisywanych zagadnień dokonano na podstawie danych dotyczących realizacji inwestycji drogowych w województwie mazowieckim.

\section{NAJWAŻNIEJSZE ZAŁOŻENIA I ZAPISY SPECUSTAWY DROGOWEJ}

Ustawa o szczególnych zasadach przygotowania i realizacji inwestycji w zakresie dróg krajowych, zwana specustawą drogową, została uchwalona 10 kwietnia 2003 r. (Dz.U. $2003 \mathrm{nr} 80$ poz. 721). Od tego czasu do chwili obecnej była ona kilkukrotnie nowelizowana (m.in. w 2006, 2008, 2009 i 2015 roku). Po nowelizacji w 2006 roku ustawę zmieniono przede wszystkim w zakresie obszaru obowiązywania w stosunku do kategorii dróg. Wcześniej regulowała ona kwestie związane wyłącznie z drogami krajowymi, natomiast po wspomnianej zmianie dotyczyła również dróg nie tylko krajowych, ale także innych dróg publicznych, takich jak: wojewódzkie, powiatowe czy gminne. Od tego momentu ustawa uzyskała nowe brzmienie: „o szczególnych zasadach przygotowania i realizacji inwestycji w zakresie dróg publicznych”. Po aktualizacji w 2015 roku (Dz.U. 2015 poz. 2031) ustawa będzie obowiązywała do grudnia 2023 roku. Reguluje ona zasady i warunki przygotowania inwestycji w zakresie dróg publicznych $\mathrm{w}$ rozumieniu przepisów ustawy o drogach publicznych. Co należy rozumieć przez definicję „,budowy”, określa art. 3, pkt 6 ustawy - Prawo budowlane: „wykonywanie obiektu budowlanego w określonym miejscu, a także odbudowę, rozbudowę, nadbudowę obiektu budowlanego" (Ustawa z dnia 7 lipca 1994 r. - Prawo budowlane. Dz.U. 2013 poz. 1409 z późn. zm.). Natomiast art. 4, pkt. 2 ustawy o drogach publicznych definiuje pojęcie „droga” jako „budowlę wraz z drogowymi obiektami inżynierskimi, urządzeniami oraz instalacjami, stanowiącą całość techniczno-użytkową, przeznaczoną do prowadzenia ruchu drogowego, zlokalizowaną w pasie drogowym" (Dz.U. 2003, poz. 260). Jak wynika z przytoczonych zapisów, ich ramy ograniczają się jedynie do rodzaju robót budowlanych polegających na budowie czy też rozbudowie drogi publicznej. I właśnie w takim zakresie 
ograny administracji architektoniczno-budowlanej interpretują zakres przedmiotu tej ustawy. W pierwotnym zamyśle ustawodawcy przepisów powyższego aktu prawnego nie stosowano do przebudowy bądź remontu drogi, gdyż ustawa ta służyć miała jedynie przyspieszeniu realizowanych inwestycji drogowych, głównie ze względów proceduralnych, związanych z nieuregulowanym stanem prawnym nieruchomości, przez które miałaby przebiegać taka inwestycja. Warto jednak zauważyć, że kolejne aktualizacje rozszerzyły w pewnym zakresie stosowanie omawianej ustawy.

Należy zwrócić uwagę na zależność prawną między omawianą specustawą a ustawą - Prawo budowlane. W świetle obowiązujących przepisów ustawa o szczególnych zasadach przygotowania i realizacji inwestycji w zakresie dróg publicznych stanowi lex specjalis, jako lex generali w stosunku do ustawy - Prawo budowlane. Oznacza to, że specustawa drogowa jest ustawą szczególną i działa ponad ustawą ogólną - Prawo budowlane. Ze względu na treść specustawy, zmieniającą się podczas kolejnych aktualizacji, zmieniała się również sytuacja prawna poszczególnych procedur administracyjnych. I tak np. przed wejściem w życie nowelizacji w 2008 roku na podstawie specustawy drogowej procedowano jedynie postępowanie w zakresie ustalenia lokalizacji drogi, konsekwentnie uzyskując pozwolenia na budowę w trybie i na zasadach określonych w ustawie - Prawo budowlane. Aktualnie rozstrzygnięcia administracyjne w zakresie budowy dróg mogą być wydawane jedynie na podstawie ustawy szczególnej. Oznacza to, że pomimo uwzględnienia w miejscowym planie zagospodarowania przestrzennego lokalizacji drogi publicznej nie ma możliwości wydania orzeczenia w kwestii pozwolenia na jej budowę. Niezgodne również będzie, w przypadku braku planu zagospodarowania przestrzennego, wydanie decyzji o ustaleniu lokalizacji inwestycji celu publicznego drogi publicznej. Bowiem w tej kwestii przepisy prawa nie przewidują żadnej alternatywy, co reguluje art. 11, ust. 2 specustawy drogowej, który po aktualizacji mówi: „W sprawach dotyczących zezwolenia na realizację inwestycji drogowej nie stosuje się przepisów o planowaniu i zagospodarowaniu przestrzennym" (Dz.U. 2003 poz. 260). Natomiast art. 11, ust. 1 mówi o tym, że w sprawach dotyczących zezwolenia na realizację inwestycji drogowej nieuregulowanych w specustawie stosuje się odpowiednio przepisy ustawy - Prawo budowlane. Wyjątek stanowi stosowanie art. 28, ust. 2 tej ustawy. Oznacza to, że wyłącznie w sytuacji, gdy ustawa szczególna nie reguluje pewnych kwestii proceduralnych, regulacji prawnych należy szukać w ustawie - Prawo budowlane oraz w Kpa. W efekcie tych zapisów znowelizowana ustawa drogowa rozstrzyga zarówno w materii zlokalizowania drogi, jak i pozwolenia na budowę. Trzeba również zauważyć, że zgodnie z Kpa (Dz.U. $1960 \mathrm{nr} 30$ poz. 23 z późn. zm.), decyzja o zezwoleniu na realizację inwestycji drogowej jest ostateczna dopiero po upływie przewidzianego terminu na wniesienie ewentualnego odwołania lub wydania orzeczenia przez organ wyższej instancji (14 dni od jej doręczenia).

Jeżeli chodzi o kolejne nowelizacje, to w 2003 roku ustawa obejmowała swoimi ramami wyłącznie drogi krajowe w zakresie wydania decyzji o ustaleniu lokalizacji drogi, zatwierdzając wprawdzie podziały, jednakże nie powodując skutków własnościowych, które należało nabyć w drodze umowy bądź wywłaszczenia. Zmiana ustawy z dnia 18 października 2006 roku rozszerzyła zakres działania ustawy na wszystkie drogi publiczne. Decyzja lokalizacyjna wydawana na podstawie tych przepisów zatwierdzała również podziały nieruchomości oraz wywoływała skutki prawne - przejęcie własności z mocy prawa, jednakże nie ustalała odszkodowania za przejęte nieruchomości (odszkodowanie ustalane było w odrębnej decyzji). Zachowano w niej również wyłączenie stosowania przepisów o planowaniu i zagospodarowaniu przestrzennym.

Zmiana ustawodawcza z 25 lipca 2008 roku wprowadziła decyzję o zezwoleniu na realizację inwestycji drogowej (tzw. ZRID), która konsolidowała decyzję o ustaleniu lokalizacji drogi i udzieleniu pozwolenia na budowę, zatwierdzała podziały nieruchomości, które w konsekwencji powodowały przejęcie własności z mocy prawa oraz wygaszenie ograniczonych praw rzeczowych, zatwierdzała projekt budowlany, nakładała obowiązek przebudowy sieci uzbrojenia terenu oraz dróg innej kategorii. Natomiast odszkodowanie ustalane było w odrębnej decyzji. Aktualizacja ta połączyła również dwa dotychczas odrębne postępowania administracyjne - ustalenie lokalizacji drogi i pozwolenie na budowę, w jedną decyzję o zezwoleniu na realizację 
inwestycji drogowej. Regulowała kwestie właściwości organów, w przypadku gdy wniosek obejmował obszar więcej niż jednego województwa, udzielała zezwolenia na dokonanie przebudowy istniejących sieci uzbrojenia terenu oraz przebudowy dróg innej kategorii, bez potrzeby uzyskiwania odrębnych decyzji administracyjnych. Wprowadziła również sankcje finansowe dla organu, który nie wydał decyzji ZRID w terminie 90 dni od dnia złożenia kompletnego wniosku. Z dniem, w którym powyższa decyzja stała się ostateczna, wygasały ograniczone prawa rzeczowe ustanowione na objętej decyzją nieruchomości bądź na prawie użytkowania wieczystego. Również w przypadku, gdy inwestycji drogowa wymagała przejścia przez tereny wód płynących bądź tereny linii kolejowej, właściwy zarządca drogi był uprawniony do nieodpłatnego zajęcia terenu na czas realizacji inwestycji (Szafranko, 2010), natomiast na Lasy Państwowe nakładała obowiązek nieodpłatnej wycinki drzew i krzewów oraz ich uprzątnięcie.

Nowelizacja z 2009 roku, oprócz kilku innych zapisów, w większym stopniu zabezpieczyła prawa osób wywłaszczanych. I tak w przypadku decyzji ZRID, której nadano rygor natychmiastowej wykonalności, decyzja ustalająca wysokość odszkodowania powinna zapaść w terminie 60 dni od dnia nadania jej rygoru natychmiastowej wykonalności. Wprowadzono równie zapis, w którym wskazano, że na wniosek osoby uprawnionej do otrzymania odszkodowania za nieruchomości wypłaca się zaliczkę w wysokości 70\% odszkodowania ustalonego przez organ I instancji. Wypłata zaliczki następuje jednorazowo w terminie $30 \mathrm{dni}$. Ponadto ustalono, że osoba, której wypłacono zaliczkę lub jej spadkobiercy, zobowiązani są do zwrotu zaliczki po jej waloryzacji na dzień zwrotu, jeżeli decyzja ZRID została zmieniona, uchylona w całości lub w części dotyczącej tej osoby lub stwierdzono jej nieważność. Powyższe zapisy ustawy zdecydowanie działają na korzyść osoby wywłaszczonej decyzją ZRID, dlatego że znacznie skróciły wypłatę należnych im odszkodowań. W praktyce organ I instancji, orzekający o wysokości odszkodowania, nie mógł dotychczas orzekać w tej sprawie, bowiem jedynie na podstawie ostatecznej decyzji ZRID mógł wszcząć postępowanie co do ustalenia jego wysokości. Należy zwrócić również uwagę na obowiązek zapewnienia lokalu zamiennego, w przypadku gdy decyzja ZRID opatrzona została rygorem natychmiastowej wykonalności i dotyczyła nieruchomości zabudowanej budynkiem mieszkalnym lub w którym został wyodrębniony lokal mieszkalny.

Reasumując, specustawa określa procedurę (Wolanin, 2010):

- ustalania lokalizacji dróg publicznych poprzez wyznaczanie ich linii rozgraniczających,

- zatwierdzania podziałów nieruchomości dla wydzielenia ich części znajdujących się w liniach rozgraniczających drogi publiczne,

- zatwierdzenia projektu budowlanego,

- zezwalania na wykonanie przebudowy istniejącej sieci uzbrojenia terenu,

- zezwalania na wykonanie przebudowy dróg innych kategorii,

- przejmowania prawa własności nieruchomości pod drogi publiczne i ustalania odszkodowania za przejęte i wygaszone prawa do tych nieruchomości,

- czasowego zajmowania terenów związanych z budową drogi publicznej,

- usuwania drzew i krzewów z nieruchomości znajdujących się w liniach rozgraniczających drogi publiczne,

- zezwalania na użytkowanie dróg publicznych i innych drogowych obiektów inżynierskich. Po zmianie w 2015 roku ustawa określa również procedurę:

- rozbiórki istniejących obiektów budowlanych (również zlokalizowanych poza projektowanymi liniami rozgraniczającymi teren),

- zezwalania nie tylko na przebudowę, ale również na budowę sieci uzbrojenia terenu,

- zezwalania na budowę lub przebudowę urządzeń wodnych lub urządzeń melioracji wodnych szczegółowych,

- zezwalania nie tylko na przebudowę, ale również budowę innych dróg publicznych,

- zezwalania na budowę lub przebudowę zjazdów. 


\section{NAJCZĘSTSZE BŁĘDY POPEŁNIANE PRZEZ INWESTORA - ZARZĄDCĘ DROGI ZWIĄZANE Z UZYSKANIEM DECYZJI ZRID}

Właściwy zarządca drogi, która ma być przedmiotem inwestycji, składa do odpowiedniego organu administracji architektoniczno-budowlanej wniosek o wydanie zezwolenia na realizację inwestycji drogowej (ZRID), w trybie art. 11a, ust. 1 ustawy o szczególnych zasadach przygotowania i realizacji inwestycji w zakresie dróg publicznych (specustawy). Właściwym organem do wydania takiej decyzji jest wojewoda w odniesieniu do dróg krajowych i wojewódzkich albo starosta w odniesieniu do dróg powiatowych i gminnych. Wraz z wnioskiem należy przedłożyć niezbędne informacje i załączniki, które muszą być przygotowane zgodnie z obowiązującymi wymaganiami. W konsekwencji wniosek zarządcy drogi powinien być tak sformułowany, aby odnosił się do każdego punktu wymienionego jako załącznik do wniosku o wydanie ZRID w taki sposób, aby nie powstała żadna wątpliwość w trakcie jego analizy. Jeżeli wniosek będzie niekompletny, wówczas inwestor zostanie wezwany, zgodnie z Kpa, do jego uzupełnienia oraz pouczony, że nieuzupełnienie wskazanych braków w terminie 7 dni skutkować będzie pozostawieniem sprawy bez rozpoznania, co oznacza, że w celu uzyskania decyzji ZRID wymagane będzie złożenie nowego wniosku wraz z kompletem załączników.

Najczęstsze nieprawidłowości w składanych wnioskach to (Zawadewicz, 2015):

1. Nieprecyzyjne określenie przedmiotu wniosku lub rozbieżności pomiędzy wnioskiem i projektem budowlanym. Inwestor, składając wniosek, ma obowiązek określić rodzaj i zakres planowanych robót, który następnie jest weryfikowany pod względem zgodności z zapisami specustawy i Prawa budowlanego. Nie jest rzadkością, że złożony wniosek wskazuje jako cel rodzaj robót lub obiekty, które nie podlegają przepisom specustawy, np. wniosek dotyczy budowy skrzyżowania, gdy faktyczny zakres robót wskazuje na jego rozbudowę związaną ze zmianą istniejących granic pasa drogowego.

2. Rozbieżności pomiędzy dokumentami ewidencyjnymi i projektem budowlanym. Jednym z podstawowych błędów, które bardzo często są dostrzegane dopiero na etapie złożonego wniosku, są nieścisłości pomiędzy numerami ewidencyjnymi działek oraz innymi dokumentami wniosku. Często rozbieżności te dotyczą numerów ewidencyjnych działek i ich obrębów ewidencyjnych, zwłaszcza gdy dokonywano podziału części działek. Należy dodać, że elementem wniosku, stanowiącym jego załącznik, są również mapy podziałowe. Jeżeli będą one zawierały błędy, co zdarza się bardzo często (np. ze względu na nieprawidłową numerację działek lub powierzchni w przypadku wykazu zmian gruntowych), ich uzupełnienie i przedłożenie tożsamych z wnioskiem będzie wymagało ponownego sporządzenia przez uprawnionego geodetę i zatwierdzenia przez właściwego starostę, co zazwyczaj jest czasochłonne.

3. Niedostosowanie projektu budowlanego do wymogów zawartych w rozporządzeniu w sprawie szczegółowego zakresu i formy projektu budowlanego oraz niezgodnego z uzyskanymi opiniami, pozwoleniami i decyzjami niezbędnymi dla wnioskowanej inwestycji. Projekt budowlany podlegający weryfikacji przez organ orzekający o wydaniu decyzji ZRID często nie spełnia nałożonych wymogów. Na przykład projekt budowlany obejmuje szerszy zakres inwestycji niż zakres objęty decyzją o środowiskowych uwarunkowaniach zgody na realizację inwestycji, czy też jest niezgodny z warunkami technicznymi wydanymi przez gestorów sieci lub jest sprzeczny z zapisami w pozwoleniu wodnoprawnym. Wymóg dotyczący uzupełnienia lub korekty odpowiedniego fragmentu dokumentacji projektowej może opóźnić wydanie pozytywnej decyzji nawet o kilka miesięcy. Należy również zauważyć, że opóźnienie związane z wykonaniem wymaganych poprawek dokumentacji projektowej może spowodować utratę ważności części wydanych zgód i uzgodnień, i zmusi inwestora do ich ponownego uzyskania.

4. Braki w złożonej dokumentacji. Dotyczy to np. nieprzedłożenia raportu o oddziaływaniu przedsięwzięcia na środowisko, map, wykazów zmian gruntowych i określenia zmian w dotychczasowej infrastrukturze zagospodarowania terenu lub analiz powiązania drogi z innymi drogami publicznymi, aktualnych wypisów z ewidencji 
gruntów obejmujących wszystkich właścicieli nieruchomości objętych przedsięwzięciem czy niedołączenie do wniosku wymaganych prawem opinii.

Generalnie, największą trudnością w pozytywnym zaopiniowaniu składanych wniosków (i dołączonej do nich dokumentacji projektowej z załącznikami) jest ich niespójność i wewnętrzna sprzeczność oraz brak wszystkich wymaganych przepisami prawa dokumentów. Składanie nierzetelnych i niekompletnych wniosków ma znaczny wpływ na wydłużenie prowadzonych przez wojewodę lub starostę postępowań administracyjnych w sprawie wydania decyzji ZRID, a tym samym znacząco wpływa na czas realizacji tych inwestycji. W takim przypadku, a dotyczy to zwłaszcza dużych, skomplikowanych, a także lokalnie kontrowersyjnych inwestycji drogowych, zezwolenia na realizację tych inwestycji nie zostają wydane w ustawowym terminie 90 dni, lecz mogą zostać wydane nawet po ponad roku.

\section{ODSZKODOWANIA ZA NIERUCHOMOŚCI PRZEJĘTE POD DROGI PUBLICZNE}

Kwestie nabywania nieruchomości pod drogi reguluje rozdział 3 omawianej specustawy. Fundamentalne znaczenie dla zrozumienia zasady nabycia działek przeznaczonych pod droge $\mathrm{z}$ mocy prawa na rzecz podmiotu publicznoprawnego ma treść art. 12, ust. 4 tej ustawy. Przepis ten stanowi, że z dniem, w którym decyzja ZRID stała się ostateczna, nieruchomości lub ich części przeznaczone na pasy drogowe (o których mowa $\mathrm{w}$ art. 11f, ust. 1, pkt 6 tej ustawy) stają się z mocy prawa własnością Skarbu Państwa w odniesieniu do dróg krajowych lub własnością odpowiednich jednostek samorządu terytorialnego w odniesieniu do dróg wojewódzkich, powiatowych i gminnych. Nabycie nieruchomości na rzecz podmiotów publicznoprawnych nie jest przedmiotem rozstrzygania $w$ ramach klasycznego wywłaszczenia, lecz następuje z mocy prawa. Skutkiem prawnym takiej decyzji ZRID jest również wygaszenie prawa użytkowania wieczystego nieruchomości przeznaczonych pod pasy drogowe. Dodatkowo art. 12 ust. 4c specustawy stanowi, że jeżeli na nieruchomości lub prawie użytkowania wieczystego zostały ustanowione ograniczone prawa rzeczowe, to prawa te wygasają z dniem, kiedy decyzji ZRID stanie się ostateczna. Ponadto z dniem, kiedy decyzja ZRID stanie się ostateczna, wygaśnięcie trwałego zarządu ustanowionego na nieruchomości przeznaczonej pod pas drogowy, stanowiącej własność Skarbu Państwa lub jednostki samorządu terytorialnego, następuje z mocy prawa. Wyjątkiem tutaj jest sytuacja, gdy na tej nieruchomości jest ustanowiony trwały zarząd na rzecz właściwego zarządcy albo zarządcy drogi. Natomiast w sytuacji, gdy taka nieruchomość została uprzednio wydzierżawiona, wynajęta lub użyczona, decyzja ZRID stanowi podstawę do wypowiedzenia przez właściwego zarządcę drogi umowy dzierżawy, najmu lub użyczenia w trybie natychmiastowym. Pozostałe obciążenia, tzn. najem, dzierżawa czy użyczenia na gruntach niebędących własnością Skarbu Państwa lub jednostki samorządu terytorialnego oraz trwały zarząd samorządowych jednostek organizacyjnych, wygasają z upływem 3 miesięcy od dnia, w którym decyzji ZRID stanie się ostateczna.

Przepisy specustawy wskazują również, że organem kompetentnym do wydania decyzji ustalającej wysokość odszkodowania jest organ, który wydał decyzję ZRID. Odszkodowanie powinno odpowiadać, co do zasady, wartości rynkowej nieruchomości, czyli najbardziej prawdopodobnej cenie, która jest możliwa do uzyskania na rynku (Gdesz i Trembecka, 2011), a ustalenie wysokości odszkodowania następuje po uzyskaniu opinii rzeczoznawcy majątkowego. Postępowanie odszkodowawcze wszczyna się z urzędu i teoretycznie decyzja o wysokości odszkodowania powinna zapaść w terminie 30 dni. Biorąc jednak pod uwagę konieczność sporządzenia opinii przez rzeczoznawcę majątkowego, ustosunkowanie się stron do tej opinii i wyjaśnienie przez rzeczoznawcę zgłoszonych zastrzeżeń (obowiązek taki wynika z zapisów Kpa polegających na zapewnieniu stronom czynnego udziału w postępowaniu administracyjnym), termin ten zazwyczaj nie jest dotrzymywany. $Z$ drugiej strony specustawa przewiduje, że jeżeli decyzji ZRID nadany został rygor natychmiastowej wykonalności, decyzję ustalającą wysokość odszkodowania wydaje się w terminie 60 dni od dnia nadania ww. rygoru tej decyzji. Przykładowe liczby decyzji odszkodowawczych oraz kwoty odszkodowań przyznanych przez wojewodę mazowieckiego w odniesieniu do dróg krajowych i wojewódzkich w latach 2012-2015 podano w tabeli 1 (MUW, 2015). 
Połoński, M. i Zawadewicz, M. (2017). Analiza skutków wdrożenia specustawy jako procedury przygotowania inwestycji drogowych w Polsce. Acta Sci. Pol. Architectura, 16 (1), 25-34. doi: 10.22630/ASPA.2017.16.1.03.

Tabela 1. Liczba decyzji i kwoty odszkodowań wydanych przez wojewodę mazowieckiego (MUW, 2015)

Table 1. Number of decisions and the amount of compensation issued by the Governor of the Mazowieckie (MUW, 2015)

\begin{tabular}{|c|c|c|c|c|}
\hline \multirow{2}{*}{$\begin{array}{l}\text { Rok } \\
\text { Year }\end{array}$} & \multicolumn{2}{|c|}{$\begin{array}{l}\text { Drogi krajowe, w tym autostrady } \\
\text { National roads, including motorways }\end{array}$} & \multicolumn{2}{|c|}{$\begin{array}{l}\text { Drogi wojewódzkie } \\
\text { Provincial roads }\end{array}$} \\
\hline & $\begin{array}{l}\text { Liczba decyzji } \\
\text { Number of decisions }\end{array}$ & $\begin{array}{c}\text { Kwota odszkodowań [zł] } \\
\text { Amount of compensation } \\
{[\text { PLN] }}\end{array}$ & $\begin{array}{l}\text { Liczba decyzji } \\
\text { Number of decisions }\end{array}$ & $\begin{array}{c}\text { Kwota odszkodowań [zł] } \\
\text { Amount of compensation } \\
{[\text { PLN] }}\end{array}$ \\
\hline 2012 & 193 & 133047485 & 236 & 62954919 \\
\hline 2013 & 161 & 54679949 & 445 & 48199446 \\
\hline 2014 & 447 & 105708680 & 233 & 28473925 \\
\hline 2015 & 538 & 49970530 & 182 & 14057073 \\
\hline
\end{tabular}

Jak już wspomniano, specustawa przewiduje również możliwość wypłaty na wniosek osoby uprawnionej jednorazowej zaliczki w wysokości 70\% odszkodowania ustalonego przez organ pierwszej instancji, jednak praktyka wykazała, że tylko nieliczna grupa uprawnionych korzysta z tej możliwości (Zawadewicz, 2015).

Ważnym przepisem zawartym w specustawie jest art. 13, ust. 3, stanowiący, że w przypadku przejęcia części nieruchomości, gdy pozostała jej część nie nadaje się do prawidłowego użytkowania na dotychczasowe cele, na wniosek właściciela właściwy zarządca drogi jest zobowiązany do nabycia tej pozostałej części nieruchomości. Zapis ten ma również odzwierciedlenie w zarządzeniu Generalnego Dyrektora Dróg Krajowych i Autostrad z dnia 11 maja 2009 roku w sprawie stadiów i składu dokumentacji projektowej dla dróg i mostów w fazie przygotowania tych zadań. Określono w nim m.in., że linie rozgraniczające teren inwestycji powinny być projektowane z uwzględnieniem uwarunkowań dotyczących istniejących podziałów nieruchomości, co oznacza, że np. niedopuszczalny jest dowolny podział przez istniejące budynki, konieczne jest zapewnienie dostępu do dróg publicznych dla działek powstałych w wyniku podziału, należy unikać podziałów powodujących brak możliwości racjonalnego zagospodarowania części nieruchomości pozostających poza liniami rozgraniczającymi teren.

Przepisy regulują również sposób odszkodowań za wygaśnięcie hipoteki lub ustanowionych ograniczonych praw rzeczowych (Ministerstwo Infrastruktury, 2010; Antoniak, Cherka, Elżanowski i Wąsowski, 2012). Specustawa wprowadza również dwa dodatki do odszkodowania. Pierwszy z nich jest to dodatek za wcześniejsze wydanie nieruchomości lub za opróżnienie lokali i innych pomieszczeń w wysokości 5\% wartości nieruchomości, gdy została ona wydana zarządcy drogi w terminie 30 dni od dnia, w którym decyzja stała się ostateczna. Drugi, w wysokości 10000 zł, przysługuje właścicielom nieruchomości zabudowanych budynkiem lub lokalem mieszkalnym przeznaczonym do rozbiórki (przyznawane w każdej sytuacji).

Niezależnie od obowiązujących przepisów ciekawe wnioski płyną z kontroli przeprowadzonej przez organy NIK w zakresie nabywanie przez Skarb Państwa nieruchomości pod drogi krajowe objęte Programem Budowy Dróg Krajowych w latach 2008-2013 (NIK, 2013). Kontrolą objęto działalność Mazowieckiego Urzędu Wojewódzkiego oraz warszawski oddział GDDKiA. O ile nie stwierdzono większych uchybień w zakresie stosowania obowiązujących przepisów, to wskazano na znaczne przekraczanie ustawowych terminów w zakresie wyceny i regulowania części zobowiązań wynikających z wydanych decyzji odszkodowawczych. Opóźnienia te w dużej mierze spowodowane zostały faktem, że opracowanie operatów wyceny wywłaszczanych nieruchomości wszczynane było po uzyskaniu ostatecznej decyzji ZRID, natomiast okres przeprowadzania poszczególnych postępowań (biorąc pod uwagę określone w procedurach terminy przewidziane na poszczególne działania) wynosił szacunkowo od około 185 do 200 dni (w zależności od stanu prawnego nieruchomości). Okres ten 
często wydłużał się dodatkowo ze względu na konieczność przeprowadzenia procedury zgodnej z ustawą o zamówieniach publicznych przy wyłanianiu podmiotów, którym można było zlecić wykonanie wyceny. Spowodowało to, że zarówno umowy na wykonanie operatów szacunkowych, jak i szczegółowe zlecenia wystawiane w ramach realizacji umów podpisywane były po upływie kilkunastu miesięcy od daty wydania przez wojewodę decyzji ZRID i po upływie kilku lub kilkunastu miesięcy od daty, w której poszczególne $\mathrm{z}$ tych decyzji stały się decyzjami ostatecznymi. Pomimo że terminy sporządzenia operatów określano w umowach na stosunkowo krótki okres - od 14 do 30 dni od daty podpisania szczegółowego zlecenia, to ostatecznie decyzje ustalające wysokość odszkodowania wydane zostały przez wojewodę w okresie od roku do trzech lat od daty wydania decyzji ZRID i w okresie od 6 miesięcy do 2 lat od daty, w której poszczególne decyzje stały się ostateczne. W raporcie zwrócono również uwagę, że strony postępowań odszkodowawczych oraz autorów skarg nie informowano na bieżąco o przyczynach zwłoki i planowanym terminie załatwienia sprawy.

\section{PODSUMOWANIE}

Ustawa o szczególnych zasadach przygotowania i realizacji inwestycji w zakresie dróg publicznych jest niezwykle ważnym narzędziem umożliwiającym szybką i sprawną realizację inwestycji drogowej. Jednak ze względu na swój wyjątkowy charakter jest ustawą budzącą wiele kontrowersji, szczególnie jeżeli chodzi o uproszczenie procedury przejmowania i podziału nieruchomości pod projektowane drogi bez wyraźniej zgody właściciela działki. Tak więc, pomimo braku przyzwolenia właściciela nieruchomość może zostać wywłaszczona pod inwestycję w zakresie dróg publicznych, przy czym należy podkreślić, iż często kwestią sporną jest wysokość wypłaconego odszkodowania za przejętą pod drogę działkę. Warto zauważyć, że każdy wniosek o wydanie decyzji ZRID jest rozpatrywany indywidualnie, dlatego każdorazowo podczas prowadzenia takiego postępowania administracyjnego powstają różne problemy, które generują kolejne pytania i wątpliwości zarówno inwestorów, właścicieli przejmowanych działek, jak i organów orzekających.

Ważne jest, aby przed przystąpieniem do realizacji procedury administracyjnej o wydanie decyzji ZRID inwestor przygotował poprawnie wszystkie niezbędne dokumenty wymagane przepisami prawa. Należy pamiętać, że zgodnie z orzecznictwem sądów to inwestor jest kreatorem przebiegu i kształtu inwestycji, w tym wypadku budowy lub rozbudowy drogi, natomiast organ orzekający odpowiedzialny jest za weryfikację złożonego wniosku pod względem jego zgodności z obowiązującymi przepisami oraz sprawdzenie, czy wyznaczone przez wnioskodawcę linie rozgraniczające pas drogowy odpowiadają woli ustawodawcy. Dlatego też z chwilą złożenia wniosku do organu orzekającego nie ma on już możliwości korekty kształtu inwestycji, co również powoduje, że ten etap realizacji inwestycji jest dość trudny i przyczynia się do powstawania tak wielu sporów.

Analizując wydawane decyzje ZRID na podstawie zapisów specustawy, należy zauważyć co najmniej dwa obszary, które budzą najwięcej wątpliwości i problemów (pomijając problem terminowości sporządzania wycen i wypłat odszkodowań). Pierwszy z nich dotyczy wysokości przyznawanych odszkodowań. Należy zauważyć, że wysokość przyznawanego odszkodowania zgodnie z zapisami specustawy związana jest wyłącznie z wartością wywłaszczanej nieruchomości i nie rekompensuje innych strat, takich jak: utrata źródła utrzymania, zmiana miejsca zamieszkania, dodatkowe koszty przedterminowej spłaty kredytu, utracone korzyści z tytułu odsetek czy straty moralne. Trudno więc się dziwić, że pomimo dopełnienia obowiązujących procedur oraz faktu, że kwoty odszkodowań były zgodne z wyceną rzeczoznawców majątkowych, co najmniej część wywłaszczonych osób czuje się potraktowana niesprawiedliwie.

Drugi problem dotyczy wywłaszczenia z prawa własności nieruchomości ponad zakres niezbędny i konieczny dla realizacji inwestycji drogowej. Niestety praktyka wskazuje, że inwestor często wnioskuje o przejęcie nieruchomości lub jej części nie tylko w ramach koniecznego zakresu przedmiotowej inwestycji, ale również poza nią. Dotyczy to najczęściej zabezpieczenia terenu pod planowaną w bliżej nieokreślonej przyszłości kontynuację inwestycji drogowej (nazywanej zazwyczaj rezerwą). Inwestorzy często wnioskują również o wywłaszczenia 
np. w celu zapewnienia określonej nieruchomości (np. marketu, budynku z usługami handlowymi, urzędu, kościoła, cmentarza) dostępu do drogi publicznej, nawet gdy znajduje się ona w znacznej odległości od projektowanych linii rozgraniczających budowy lub rozbudowy drogi.

Jednakże najczęstszym zarzutem wobec inwestora jest próba wywłaszczenie terenów pod budowę parkingów, nazywanych we wniosku i projekcie budowlanym np. zatokami postojowymi, zatokami parkingowymi czy miejscami parkingowym do obsługi drogi (w odróżnieniu od np. niezbędnych zatok autobusowych). Wszelkie tego typu roszczenia inwestora są naruszeniem zapisów omawianej specustawy.

Reasumując, można stwierdzić, że specustawa drogowa spełniła swoje zadanie w zakresie przyspieszenia i usprawnienia określonych procedur administracyjnych i jest niezbędnym narzędziem prawnym do szybkiej realizacji sieci dróg w naszym kraju, a tym samym bezpośrednio wpływa na rozwój komunikacyjny państwa i jego gospodarki. Ustawa jest chętnie, skutecznie oraz maksymalnie wykorzystywana przez podmioty uprawnione, tj. przez zarządców dróg publicznych. I tak np. w województwie mazowieckim w latach 2008-2013 przeprowadzono 4982 postępowania wywłaszczeniowe i odszkodowawcze, a wojewoda na wniosek GDDKiA wydał 1961 decyzji o wywłaszczeniu nieruchomości przeznaczonych pod budowę dróg krajowych (NIK, 2013).

Kumulacja kilku postępowań administracyjnych w jednym daje inwestorom wiele możliwości prawnych sprawnej i szybkiej realizacji inwestycji drogowej. Jednak zawarte w niej uproszczenia proceduralne, obowiązujące ponad Prawem budowlanym, podnoszą ryzyko popełnienia błędu powodującego trudne do odwrócenia skutki, zarówno techniczne, jak i prawne. Aby uniknąc tych błędów, niezbędny jest wysiłek i staranność inwestora i projektanta na etapie przygotowywania wniosku, a następnie jego skrupulatna kontrola, zarówno w pierwszej, jak i drugiej instancji, przed wydaniem ostatecznej decyzji ZRID.

\section{PIŚMIENNICTWO}

Antoniak, P., Cherka, M., Elżanowski, F. M. i Wąsowski, K. A. (2012). Przygotowanie i realizacja inwestycji w zakresie dróg publicznych. Komentarz. Warszawa: Wydawnictwo LEX, WKP.

Gdesz, M. i Trembecka, A. (2011). Regulowanie stanu prawnego nieruchomości. Katowice: Wydawnictwo Gall.

Mazowiecki Urząd Wojewódzki [MUW] (2015). Dane udostępnione przez Wydział Skarbu Państwa i Nieruchomości, Oddział Nieruchomości Drogowych. Warszawa.

Ministerstwo Infrastruktury (2010). Wybrane zagadnienia dotyczące odszkodowania za nieruchomości przejęte pod drogi. Warszawa.

Najwyższa Izba Kontroli [NIK] (2013). Wystapienie pokontrolne nr P/13/157. Nabywanie przez Skarb Państwa nieruchomości pod drogi krajowe objęte Programem Budowy Dróg Krajowych w latach 2008-2013. Druki nr: LWA - 4101-013-01/2013 i LWA - 4101-013-02/2013. Warszawa.

Połoński, M., red. (2009). Proces inwestycyjny i eksploatacja obiektów budowlanych. Warszawa: Wydawnictwo SGGW.

Sobotka, A., Jaśkowski, P., Czarnigowska, A., Pawluś, D. i Wałach, D. (2014). Zarządzanie łańcuchami dostaw w budownictwie. Wybrane metody i modele w budownictwie drogowym. Kraków: Wydawnictwo AGH.

Szafranko, E. (2010). Procedura związana z przygotowaniem inwestycji drogowej w świetle specustawy. Czasopismo Techniczne. Budownictwo, 107, 405-417.

Ustawa z dnia 14 czerwca 1960 r. - Kodeks postępowania administracyjnego. Dz.U. 1960 nr 30 po. 168 z późn. zm.

Ustawa z dnia 7 lipca 1994 r. - Prawo budowlane. Dz.U. 2013 poz. 1409 z późn. zm.

Ustawa z dnia 10 kwietnia 2003 r. o drogach publicznych. Dz.U. 2003 poz. 260.

Ustawa z dnia 10 kwietnia 2003 r. o szczególnych zasadach przygotowania i realizacji inwestycji w zakresie dróg publicznych. Dz.U. $2003 \mathrm{nr}$ 80, poz. 721 z późn. zm. (tekst jednolity).

Wolanin, M. (2010). Komentarz do Ustawy o szczególnych zasadach przygotowania i realizacji inwestycji w zakresie dróg publicznych. Wyd. 2. Warszawa: Wydawnictwo C. H. Beck.

Zawadewicz, K. (2015). Procedury administracyjne w procesie budowlanym na przykladzie realizacji inwestycji w zakresie dróg publicznych. Praca inżynierska. Warszawa: SGGW. 


\title{
ANALYSIS OF THE EFFECTS OF IMPLEMENTING THE "SPECIAL LAW" (ON ACQUIRING LAND FOR PUBLIC PROJECTS) AS A PROCEDURE FOR PREPARING ROAD INVESTMENTS IN POLAND
}

\begin{abstract}
From the moment when Poland acceded the European Union, the country gained access to large amounts of financial resources e.g. for the development of road infrastructure. However, the use of the funds was restricted by legal procedures related to the preparation and accomplishment of these investments. For enhancement of the investment process with regard to these issues, the Polish Parliament enacted a special road law, commonly known as the "specustawa", on acquiring land for public projects. It became effective in 2003 and will remain in force till 2020. Because this law is in effect already for over 10 years, the paper analyses both positive and negative effects of its implementation. It was confirmed that the "special law" is an indispensable legal act for fast accomplishment of a road network in Poland. It is readily, effectively and maximally utilized in the process of preparation and accomplishment of road investments. The accumulation of several administration procedures in one act gives the investors several legal possibilities of effective and fast accomplishment of such objects. However, procedural simplifications in the act increase the risk of committing an error, with irreversible effects, both technical and legal. The main problems linked with the implementation of the "special law" include the value of the pay compensations for the acquired land and attempts of expropriation beyond a range that is indispensable and necessary for the accomplishment of a scheduled road investment.
\end{abstract}

Key words: special road law, road investment, investment preparation, investment process, building law 